Panchenko Svitlana

$\mathrm{PhD}$ in Cultural studies, associate professor

of the Art-management and event technologies chair, the National Academy of Managerial Staff

of Culture and Arts

ORCID ID 0000-0001-8010-8318

dolga100@ukr.net

\title{
ISSUE OF FREEDOM IN RELIGIOUS TOURISM AND PILGRIMAGE
}

The Purpose of the Article is to analyze the issue of freedom in pilgrimage and religious tourism. The Methodology of the research includes applying such methods as analysis, synthesis, comparison, aggregation, as well as the use of historical and cultural approaches. The Scientific Novelty lies in the expanding and generalizing the knowledge about freedom in religious tourism. Conclusions. As a result of the preceding study, we have found that freedom in religious tourism is revealed through a variety of human activity. Tourist cognitive activity, the need for human wandering is determined by historically developed and assimilated socio-cultural programs that orient the person to the knowledge and development of the surrounding world, the construction of new systems of relationships, receiving new emotional and aesthetic impressions and assimilation of interesting forms of social experience.

Key words: truth; freedom; tourist revolution; free time, choice; removal of social tension; cultural analysis; religious tourism; pilgrimage; confession; function; experience.

Панченко Світлана Анатоліївна, кандидат культурології, доцент кафедри арт-менеджменту та івент-технологій Національної академії керівних кадрів культури і мистецтв

Питання свободи в релігійному туризмі та паломництві

Мета дослідження - вивчення питання свободи в паломництві і релігійному туризмі. Методологія дослідження полягає у застосуванні методів аналізу, синтезу, порівняння, узагальнення, а також у використанні історичного та культурологічного підходів. Наукова новизна полягає у розширенні та узагальненні знань про свободу в релігійному туризмі, яка розкривається через різновид людської дії, активності. Висновки. В результаті дослідженні встановлено, що свобода в релігійному туризмі розкривається через різновид людської дії, активності. Туристська пізнавальна активність, потреба у мандрівництві людини визначається історично виробленими і засвоєними соціокультурними програмами, котрі орієнтують особистість на пізнання і освоєння навколишнього світу, побудові нових систем взаємовідносин, отриманні особистістю нових емоційних та естетичних вражень і засвоєння нею цікавих форм соціального досвіду.

Ключові слова: істина; свобода; туристська революція; вільний час; вибір; зняття соціальної напруги; культурний аналіз; релігійний туризм; паломництво; сповідь; функція; досвід.

Панченко Светлана Анатольевна, кандидат культурологии, доцент кафедры арт-менеджмента и ивент-технологий Национальной академии руководящих кадров культуры и искусств

Вопрос свободы в религиозном туризме и паломничестве

Цель исследования - изучение вопроса свободы в паломничестве и религиозном туризме. Методология исследования заключается в применении методов анализа, синтеза, сравнения, обобщения, а также в использовании исторического и культурологического подходов. Научная новизна заключается в расширении и обобщении знаний о свободе в религиозном туризме, которая раскрывается через разнообразие человеческого действия, активности. Выводы. В результате исследования установлено, что свобода в религиозном туризме раскрывается через разнообразие человеческого действия, активности. Туристская познавательная активность, потребность в странничестве человека определяется исторически выработанными и усвоенными социокультурными программами, которые ориентируют личность на познание и освоение окружающего мира, построении новых систем взаимоотношений, получении личностью новых эмоциональных и эстетических впечатлений и усвоение ею интересных форм социального опыта.

Ключевые слова: истина; свобода; туристская революция; свободное время; выбор; снятие социальной напряженности; культурный анализ; религиозный туризм; паломничество; исповедь; функция; опыт.

The Relevance of the Topic. Studying pilgrimage is not a problem of theologians and thinkers only; this phenomenon is also interesting for historians, psychologists, culturologists, philosophers, and writers, as pilgrimage helps a person to get to know his/her spiritual essence, to return to the origin of his/her nation, to touch the cultural and spiritual heritage, to reach harmony with the spiritual world.

The phenomenon of pilgrimage synthesizes the cultural processes that take place in society. Pilgrimage remains one of the cultural phenomena that is most actively developing. Compared to other types of travel, pilgrimages relate to different areas of the economic, social and cultural life of society, and these general restraints deserve the attention of thinkers, philosophers, and scientists.

Due to the pilgrimage, the exchange of cultures, borrowing traditions, ceremonies, cults are proceeding. Ukrainians are a rather benevolent nation, their tolerant nature, positive attitude towards other cultures, shrines, and monuments can be seen during the pilgrimage journey across Ukraine.

Demand for scientific reflection and mechanisms for combining deep historical traditions with the cultural trends of the present in modern pilgrimage.

(C) Panchenko S., 2018 
Pilgrimage as a cultural phenomenon becomes the subject of scientific research only in the second half of the XX century. Before this period, most of the works are presented by empirical observations and testimonies of travel of pilgrims of the past and present or are devoted to descriptions of different shrines [11, p.8].

The main part. The transformation processes in the sphere of pilgrimage and religion tourism are one of the most researched issues in the world of science

(M. Monten, V. Gorski, F. Hegel, Z. Bauman, S. Soliyanik, G. Skovoroda, M. Berdyaev, F. Franzhialli, Jean-Paul Sartre, K. Kryvega, etc.).

The category of «freedom» in the pilgrimage is a real manifestation of the natural realization of person's social essence using tourist events, the search and "development» of freedom through tourism and travel. After all, people can identify themselves only due to the ability to show their will, to make a choice of a form of life, world orientation, behavior, to demonstrate creativity, easiness, that is, free activity.

The possibility of free travel is a basic human need, beginning with physiological and ending with cognitive, cultural, spiritual self-realization.

As V. Gorski noted fairly, «not each travel can be called tourism, and every traveler - a tourist. But no doubt that any tourist activity is wandering and every tourist is «Homo viator» - a traveler».

He writes that "the attraction of a journey for meeting others, the desire to understand other people, to join them, to expand the world of one's being, are rooted in the history of Ukrainian culture, in the depths of human mentality» [2, p.28].

Thanks to the pilgrimage tourism, the freedom that it gives to a person, we can comprehend and perceive the world around us and the Universe as a whole, its laws, and the essence, life and culture of other nations, to test ourselves in unusual extreme situations, and also to learn deeply and understand the culture of our country, our cultural horizons of perception and understanding of the world. As M. Monten once wrote: «My need for freedom is so great that if I were forbidden to access some corner located somewhere in the Indian lands, I would feel somewhat humiliated» [3, p.193].

Such an event primarily explains the urgency of the problem of freedom and tourism as the «tourist revolution», which gave humankind such a concept as free time. Even Marx said that the measure of the wealth of society is not working, but free time, when a person can realize his/her need for self-affirmation, self-development, and self-actualization [4].

Religious pilgrimage is a component of tourism with an emphasis on the socio-cultural, moral and psychological nature, spiritual purification. It should be emphasized that the phenomenon of pilgrimage is common to all denominations, but each of them has firstly its specifics, and secondly, its list of holy places: the Kyiv Pechersk and Pochayiv Lavra, Mecca, Medina, Jerusalem, Uman, and others. This approach is organically interpreted in Ukrainian society. Such phenomena as «the truth», «freedom», «tourist revolution», «free time», «choice», «removal of social tension» acquire a particular theoretical weight in the specified context.

In the context of the problems of religious pilgrimage, the category «freedom» becomes of especial importance, since in the pilgrimage it is a real manifestation of the natural realization of person's social essence by means of «tourist events» and «development» of freedom during tourist routes or travels, as well as free tourist communications, which promote self-realization of a person.

As Francesco Franziali states, «the tourist revolution of the twentieth century is as creative and important as an industrial revolution that began two centuries earlier.» Indeed, religious tourism is not only one of the most important manifestations of the freedom of a modern person, but also, most importantly, the social space in which its self-realization, moral self-determination, regulation of human relations are carried out.

However, the interpretation of freedom during the pilgrimage is impossible without the definition of democracy in general. In today's philosophical consciousness, the problem of liberty acquires a variety of interpretations, not excluding the synthesis of several approaches to its explanation. This is due, among other things, to the inexhaustibility of man and society as carriers of freedom [5].

Choosing ways to meet diverse tourist needs brings a man all the full experience of life. An individual becomes free, first of all, when he/she has a world-view free from dogmas and prejudices and has the opportunity to move freely in the social space. A person becomes open to realize his/her tourist dream, and any longer does not look like the one thrown into this world without any direction and lost in everyday minor events. When traveling, a person lives concentrated on a single dominant interest and introduces this interest in all the diversity of his/her life events.

The primary role in the situation of choice belongs to the question of the value orientation of human choice. Analyzing the dynamics of tourist travel, we see that it changes in the direction of growth of communicative, spiritual, cultural needs, that is, the needs of self-development and self-realization of personality.

An integral part of the value orientations of an individual, as V. Pazenok notes, is «tourist freedom» and freedom of the individual in general. The principal objects of tourism are not routes, hotels, campsites, tourist agencies, but the person traveling, his/her world of interests, desires, aspirations, value orientations, first of all, such as freedom [6].

The phenomenon of freedom in tourism can be seen in different planes. «First, it is the freedom of physical displacement of large contingents of people in the geographical and socio-political space - secondly, the realization of opportunities for economic freedom, which, of course, are determined by the level of 
wealth of tourists. Thirdly, ensuring an extensive range of places for travelers, where geographically they intend to relax and expand their impressions and knowledge of the world, countries that they want to visit, people with which to communicate, in which socio-cultural environment to dip.

And finally, this is the freedom for the social subject (individual, community) to identify the direction (social vector) of his/her own ideological, cultural and spiritual development, which can be stimulated by one or another type or route of a tourist trip» [7].

Traveling through different corners of the Earth, a person continually goes beyond the limits of familiar things, meets other people, other countries, and other cultures. Tourist activity appears as a «portrait» of an era, folk traditions, civilizational transformations and as a result of social differentiation, the formation of spiritual communities, etc. Tourist activity is a part of the objective process of creation of social intercourse as an actual need of people.

Tourism, as living undocumented knowledge, belongs to the system of communicative cycles: from the social space to the psychophysiological essence of an individual (the implementation of ideas, values, evaluations, attitudes, etc.) through behaviour and actions, and vice versa, from the subjective world of an individual to social space (creation of new patterns of behavior, life strategies, ideological orientations).

Freedom and pilgrimage constitutes a person as an individual, substantiates his/her solidarity with other people, that is, it determines the possibility of cooperation, the use of social experience of other communities in the realization of the person's life project [8, p.15].

Freedom in religious tourism is revealed through a variety of human activity. Tourist cognitive activity, the need for wandering is determined by historically developed and assimilated socio-cultural programs that orient a person to the exploration and mastering the surrounding world, the construction of new systems of relationships, receiving new emotional and aesthetic impressions and assimilation of interesting forms of social experience.

Pilgrimage is travel of believers to holy places (places of pilgrimage) in the hope of obtaining divine holiness. The most famous places of pilgrimage in the Christian culture are such places as Palestine, Athos, and others; in Ukraine - the Kiev-Pechersk Lavra, the Pochayiv Lavra and Svyato-girska Lavra.

Life is a test, probation, and the traveler himself, in the physical and spiritual dimensions, can be disclosed by the Supreme powers, the most secret, sacred peaks of human destiny on this earth.

Among the reasons for the pilgrimage there are the following: desire to heal from mental and physical ailments; need to pray for relatives; hope to find grace; a call to perform charitable work; expect to be forgiven for sins; an opportunity to express gratitude for the good sent from above; the duty to show allegiance to the faith; desire for asceticism in the name of religion; to find the meaning of life. Pilgrimage is the way to God, way to Absolute and the meetings with believers and their culture, visiting historical and architectural places. During a pilgrimage, we have to understand the meaning of a journey to God and Absolute working with our soul.

The everyday world of a modern man is quite sharp, pragmatic, unbalanced; the person is put in the framework of hard daily life, lives according to the standards of the present in a whirl of actual problems. In this sense, pilgrimage is salvation, salvation for the victory of the spiritual over the material.

Pilgrimage in the structure of religious tourism is considered both as a historical and cultural tradition and as an integral part of religious tourism. In this connection, we would like to emphasise the importance of pilgrimage to holy places and outline the original features of pilgrimage to the Kyiv-Pechersk Lavra.

In our research we also work out the etymology of the concept of «pilgrimage» and the history of the process of transformation of the custom to travel in places related to the cult of a specific deity into a conscious act of pilgrimage: early Christian travel was the basis of the very idea of religious pilgrimage, and absorbing the purposes of travel, the Christian pilgrimage became some kind of school, which gives a person a complete picture of life.

From the very beginning of the XXI century, the nature of pilgrimage began to change, because instead of "walking on pilgrimage» to holy places, as it was practiced in the past, in our time the saints are delivered by planes to Ukraine: relics of saints, spiritual relics, miraculous icons. Traveling to holy places is not only the Orthodox but also the Catholic tradition, which is mainly fed by the cult of the Virgin Mary and is consistently embodied in life by the Ukrainian Catholics.

At the present stage of development of cultural knowledge, it is necessary to define several types of pilgrimages, among which the following are highlighted: individual, family, group (according to the number of participants and family affiliation); by the duration (the Russian Orthodox canon of the pilgrimage appointed a trip within 10 calendar days); by seasonality (annual pilgrimages, and also confined to religious holidays); by sites of visitation, first of all, confessional places of worship (churches, monasteries, temples), as well as natural places of worship (caves, mountains, lakes); by the location of the object of the pilgrimage (internal within the state borders) and foreign pilgrimage tours; on the basis of compulsory (voluntary and mandatory pilgrim tours), because a hajj in Islam is mandatory for each orthodox Muslim.

Thus, in the context of the problems of religious pilgrimage the practical aspect of realization of religious tourism is especially important, because, proving actuality and relevance of the research of religious tourism, it is necessary to present a model of transformation of theoretical material into the practical sphere. 
Based on the general experience of memoirs and periodicals of the nineteenth century, it is relevant to recreate the logic of further pilgrimage, the implementation of pilgrimages that have undergone a severe deformation during the reign of an atheistic outlook in the conditions of Soviet reality. It is necessary to conduct a comparative analysis between the interpretation of religious tourism during the XIX century and in terms of independent statehood since the principles of continuity are the key to obtaining an objective notion about the dynamics of historical and cultural processes.

Conclusions. Religious pilgrimage, representing a long-standing cultural tradition, has been able to preserve its unchanging essence for centuries and to become an integral part of the modern world. External conditions of realization of travel by believers are changing, but the aim and content remain the same. Neither the decades of the Bolshevik period nor the political and social cataclysms of the present, have pushed away from the pilgrims and other people who seek to know and hear the right word about the life of the Pechersk Saints, about the tremendous spiritual power of the ancient spiritual shrines.

The pilgrimage form of tourism has enormous potential for promoting inter-confessional and intercultural communication as well as preserving the cultural diversity of the country. Globalization, economic liberalization, new ethnicity and religious politics, the development of science and culture, and the availability of artistic values have a positive influence on the formation of many religious objects in the modern world.

\section{תimepamypa}

1. Пазенок В. С. Феномен свободи у сучасних західних філософських концепціях. Свобода: сучасні виміри та альтернативи. Київ: Укр. Центр духовної культури, 2004. С. 11-56.

2. Горський В. С. Подорож як феномен культури. Всеукраїнський круглий стіл «Філософрія туризму». - К. : КУТЕП, 2002. - с. 28.

3. Монтень М. Опыты: в 3-х кн.: пер с фр. Кн. 3. СПб.: Кристалл: Респекс, 1998. 704 с.

4. Абрамов В.В. Туризм - вседозволенность или достижение мировой культуры. Культура і освіта фрахівців туристської сфрери: сучасні тенденції та прогнози: матеріали III Міжнар. наук.-практ. конф. Киев: КУТЕП, 2005. C. 434-438.

5. Гуманізм: сучасні інтерпретації та перспективи. Київ: Укр. Центр духовної культури, 2001. 380 с.

6. Пазенок В. С. Філософія туризму. Філософрія туризму: навч. посіб. Київ: Кондор, 2004. С. 19.

7. Федорченко В. К. Свобода: практичні виміри соціального суб'єкта. Свобода: сучасні виміри та альтернативи. Київ: Укр. Центр духовної культури, 2004. С. 469-483.

8. Кривега К. В. Туризм як прояв свободи сучасної особи. Нова парадигма. Київ: Вид-во НПУ ім. М. П. Драгоманова, 2005. Вип. 43. С. 13-24.

9. Житенёв С.Ю. Религиозное паломничество в христианстве, буддизме и мусульманстве: социокультурные, коммуникационные и цивилизационные аспекты. - Москва, 2012 - С. 130-131; С.102.

10. Khristov T. T. Religious tourism. Moscow: Academia, 2005. 288 p.

11. Крюкова Н. В. Паломництво до святих місць України (на матеріалах Кримського регіону): авторефр. дис. ... канд. фрілософ. наук: спец. 09.00.12 / Крюкова Наталія Василівна; Київ. ун-т ім. Тараса Шевченка. Київ, 2008. c. 8.

\section{References}

1. Pazenok, V.S. (2004). The phenomenon of freedom in modern Western philosophical concepts. Freedom: Modern Dimensions and Alternatives. K.: Ukr. Tsentr duhovnoyi kulturi [in Ukrainian].

2. Gorskiy, V.S. (2002). Travel as a cultural phenomenon. All-Ukrainian Round Table "Philosophy of Tourism". K. : KUTEP [in Ukrainian].

3. Monten M. (1998). Experiments. SPb.: Kristall: Respeks [in Russian].

4. Abramov, V.V. (2005). Tourism - permissiveness or the achievement of world culture. Culture and education of tourism specialists: current trends and forecasts: materials III International. science-practice conf. K: KUTEP [in Ukrainian].

5. Humanism: the future and the future (2001). Kiev: Ukr. Center for Spiritual Culture [in Ukrainian].

6. Pazenok, V.S. (2004). Philosophy of tourism. Philosophy of Tourism. Kyiv: Condor [in Ukrainian].

7. Fedorchenko, V.K. (2004). Freedom: practical dimensions of a social subject. Freedom: Modern Dimensions and Alternatives. Kiev: Ukr. Center for Spiritual Culture [in Ukrainian].

8. Kryvega, K.V. (2005). Tourism as a manifestation of the freedom of a modern person. New paradigm. Kiev [in Ukrainian].

9. Zhitenev, S.Yu. (2012). Religious pilgrimage in Christianity, Buddhism and Islam: socio-cultural, communication and civilizational aspects. Moskva: Indrik [in Russian].

10. Christov, T.T. (2005). Religious tourism. M.: Izdatel'skij centr "Akademija" [in Russian].

11. Kryukova, N.V. (2008). Pilgrimage to holy places of Ukraine (on materials of the Crimean region). Extended abstract of candidate's thesis. Kyiv [in Ukrainian].

Стаття надійшла до редакції 13.09.2018 p. 